\title{
Termite Communities in Sugarcane Plantations in Southeastern Brazil: an Ecological Approach
}

\author{
Luciane Kern Junqueira ${ }^{\bowtie}$, Edmilson Ricardo Gonçalves \& Lucas Manuel Cabral Teixeira
}

Pontifícia Universidade Católica de Campinas, e-mail: lkjunque@yahoo.com.br (Autor para correspondência ${ }^{\bowtie}$ ), erg@puc-campinas.edu.br, lteixeira@gmx.com.

\section{EntomoBrasilis 8 (2): 105-116 (2015)}

Abstract. Termites are key components of soil fauna, playing an essential role in organic matter decomposition and nutrient cycling. However, they can cause significant economic losses in commercial plantations, such as sugar cane. Therefore, the correct identification of termite species is critical for pest control. Here, we evaluated the species richness, abundance and functional groups of termites in sugarcane plantations in 53 cities throughout the state of São Paulo, southeastern Brazil. We also analyzed the influence of macroclimatic variables on termite species distribution and functional groups. We found 22 taxa of two families, of which the most frequent species were Termitidae (96.51\%). Within this family, Apicotermitinae had the highest frequency of occurrence (37.12\%), followed by Termitinae (30.57\%), Syntermitinae (27.95\%), and Nasutitermitinae (0.8 \%). The other family, Rhinotermitidae, had the lowest frequency (3.5\%), being represented only by Heterotermes sulcatus Mathews. We classified Neocapritermes opacus Hagen (29.26\%), Apicotermitinae sp.2 (24.89\%), Cornitermes cumulans Kollar (13.10\%), and Apicotermitinae sp.1 (6.99\%) as common taxa. The remaining 18 species were classified as rare. The most common functional group was humus-feeders (37\%), followed by wood-feeders (34\%), grasslitter feeders (25\%), and intermediate feeders (4\%). Climate influenced the distribution of common species, humus-feeders and grass-litter feeders. Regarding the pest status of termites in sugar cane plantations, we suggest that the exasperated use of pesticide in the last decades has reduced the abundance of species considered pests (e.g. Heterotermes) and reinforce the importance of ecological approaches for determining the best pest control methods.

Keywords: Functional groups; Heterotermes sp.; Isoptera.

\section{Comunidades de Cupins em Cultivos de Cana-de-Açúcar no Estado de São Paulo: Uma Abordagem Ecológica}

Resumo. Os cupins são importantes componentes da fauna de solo, atuando na decomposição da matéria orgânica e ciclagem de nutrientes. Porém, em cultivos de cana-de-açúcar, podem provocar perdas econômicas significativas. A correta identificação das espécies de cupins é um ponto crítico para o controle daquelas que adquiriram e/ou que podem atingir o status de praga. Este trabalho objetivou identificar a riqueza, a abundância e os grupos funcionais destes insetos em canaviais de 53 municípios do estado de São Paulo. Paralelamente, avaliou se as variáveis macroclimáticas influenciam a distribuição das comunidades de cupins e dos grupos funcionais. A riqueza obtida foi de 22 táxons. Da família Termitidae (96,51\%), a maior frequência de ocorrência foi da subfamília Apicotermitinae (37,12\%), seguindo-se Termitinae (30,57\%), Syntermitinae (27,95\%) e Nasutitermitinae (o,8\%). A família Rhinotermitidae (3,5\%) esteve representada apenas por Heterotermes sulcatus Mathews. Quatro táxons foram considerados comuns em canaviais, Neocapritermes opacus Hagen (29,26\%), Apicotermitinae sp.2 (24,89\%), Cornitermes cumulans Kollar (13,10\%) e Apicotermitinae sp.1 (6,99\%) e os 18 restantes foram classificados como raros. O grupo funcional mais frequente foi o dos humívoros (37\%), seguido por xilófagos (34\%), comedores de serrapilheira (25\%) e intermediários (4\%). O clima influenciou a distribuição das espécies comuns, bem como dos grupos funcionais dos humívoros e dos comedores de serrapilheira. Sugere-se que o uso intensivo de pesticidas nas últimas décadas reduziu a abundância de espécies até então consideradas praga em cana-de-açúcar (ex. Heterotermes), o que reforça a importância dos estudos ecológicos para a definição de métodos de controle mais adequados.

Palavras-chave: Grupos funcionais; Heterotermes sp.; Isoptera.

$\sqrt{n}$ lermite communities are usually species rich systems, with different feeding and nesting strategies. Termites are the main group involved in the intake and processing of organic and mineral matter (LAVELLE et al. 1997; JONES 2000; GATHORNE-HARDY et al. 2001), also playing a key role in the carbon decomposition and mineralization, changing the soil structure (Bignell \& EgGleton 2000; Ackerman et al. 2007). Some species seem to be more sensitive to land use than others. For example, geophagous are vulnerable to agricultural activities, which reduces species richness and abundance of this group. The decline in geophagous species is often harmful to vegetation (BANDEIRA \& VASCONCEllos 2002; BANDEIRA et al. 2003). Geophagous are associated with the increase in nitrogen and phosphorus release, drainage and aeration of the soil and humidification and stabilization of organic matter (LAVELLe et al. 1997; Dibog et al. 1999; JUNQUEIRA et al. 2008). However, given the importance of termites in maintaining the fertility, aeration, and porosity of tropical soils, studies on their reproductive biology and population dynamics should be encouraged, to improve control agents, and species-specific management techniques (Miranda et al. 2004).

On the other hand, xylophagous termites do not seem to be influenced by agricultural practices (DE SouzA \& BROwN 1994; EGGLETONetal.1997,2002; BANDEIRA\&VASCONCELLOS2002; BANDEIRA et al. 2003). Xylophagous are key components of the soil fauna in native forests, playing an essential role in the decomposition of organic matter, nutrient cycling, aeration, drainage, and the establishment of new soil in eroded areas (Collins 1981; BERTIFILHO 1995; JunQUEIRA et al. 2008). However, some species may become pests in planted forests. For example, they are known to cause significant economic damages in Eucalyptus plantations (WARDELL 1987; LAFFONT et al. 1998). More recently this group has also been mentioned as pests in sugarcane plantations (BATISTA- 
There is a growing interest in the effect of termites on sugarcane crops and planted forest. Due to the concern that some species might become pests, there is a growing body of literature dealing with reproductive biology and population dynamics of several insect species (MirANDA et al. 2004; JunQUEIRA et al. 2008; MENZEL \& Diehl 2008, 2010; ACKerman et al. 2009).

The two top countries producing sugarcane in 2007 were Brazil, with $33 \%$ of world production, and India, concentring $23 \%$ of the production (Informa Economics/FNP SOUTH America 2009). The use of sugarcane to produce biofuels increased globally in the past 30 years. The interest in this crop is promoting the adoption of more efficient farming practices that contributed to the increase in productivity (ChEAVEGATTI-GianotTo et al. 2011).

Sugarcane has been an economically important crop in Brazil since early sixteenth century. Around 7.5 million ha were cultivated with sugarcane between 2009 and 2010, producing about 612 million tons. Half of this was used in the sugar industry, while the remainder produced about 25 billion liters of ethanol and other products, such as animal food and cachaça (CONAB 2009; Cheavegatti-Gianotto et al. 2011).

Sugarcane plantation occupies a large area in Brazil, including low fertility and sandy soils. Those factors favor the occurrence of subterranean termites, which can damage different growth stages of the cane (CAMPos et al. 1988). For example, termites are major pest in sugarcane plantations in northeastern Brazil, with a high incidence of the genera Heterotermes and Neocapritermes. A previous study found four termite species in a sugarcane plantation in northeastern Brazil but only one was causing damage (Cylindrotermes nordenskioeldi Holmgren), while another (Amitermes nordestinus Mélo \& Fontes) could be a potential pest (MirANDA et al. 2004) and the abundance and spatial distribution of these species were mainly influenced by the root biomass and the amount of organic matter in the soil. Additionally, other studies (e.g., NovaretTi \& Fontes 1998) reported 14 termite species in sugarcane plantations in the southeastern part of the county, while Almeida \& Alves (1999) considered Heterotermes tenuis Hagen as the main pest species in São Paulo, due to its wide distribution and high abundance.

Here, we identify the richness, abundance and functional groups of species of termites and used species abundance distribution to define common and rare species of termites in sugarcane plantations of 53 cities in the state of São Paulo, southeastern Brazil. We also investigated in the scientific literature if the most common species are potential pests. Finally, we tested if macroclimatic variables (e.g., temperature and precipitation) and geographical distance influence the distribution of termite species and functional groups.

\section{MATERIAL AND METHODS}

Sampling and identification. We sampled termites in sugarcane plantations in 53 cities (Figure 1, Appendix 1) of the São Paulo state, Brazil. Plantations were selected by the "Centro de Tecnologia Canavieira" (Center for Sugarcane Technology, Piracicaba, São Paulo state) (collection license SISBIO \#12205-1). Sampling occurred in 2011 after the end of the sugarcane cycle, when it is harvested, along with its roots. Then, the soil is prepared with liming for a new planting (DANTAS 2011). We sampled termite by opening two burrows $\left(2,500 \mathrm{~cm}^{2}\right.$ with 30 $\mathrm{cm}$ depth) per hectare in sugarcane tussocks (following ARRIGONI et al. 1998). Each sampling was performed one month after the harvest. Collected termites were stored in entomological glazing with $80 \%$ ethanol.

We used catalogs and keys to identify termite species, including Araújo (1977), Cancello (1986, 1989), Constantino (1994, 1995, 1998, 1999, 2001, 2002a, 2002b, 2014), Constantino et al. (2006), Constantino \& CARVAlho (2011), Emerson (1952), Fontes (1985, 1992, 1995), Krishna \& Araújo (1968), Mathews (1977), Mill (1983), Rocha \& Cancello (2009), and Rocha et al. (2011, 2012a, 2012b). Species identification was confirmed by specialists (see acknowledgements). The collected specimens are housed in the Collection of Isoptera, Department of Biological Sciences, Center for Life Sciences, Pontifical Catholic University of Campinas.

Functional group definition. Functional groups were defined based on species feeding guilds (Mathews 1977; GonTIJO \& Domingos 1991; De Souza \& Brown 1994; EgGleton et al. 1995, 1997; Jones \& BRendell 1998; Jones 2000). A previous study (Bignell \& EGGLETon 2000) defined functional groups as follows: geophages, xylophagous, intermediaries between geophages and xylophagous, leaf-litter dweelers, grass-eaters, and other feeding groups (species that feed on fungi, algae, lichens, manure and vertebrate corpses).

REzEnde (2012) classified the feeding habits of South American Termitidae species based on jaw morphology of workers and intestinal contents. Thus, we followed this classification to define functional groups as wood-feeders, humus-feeders, grass-litter feeders, and intermediate feeders.

Defining common and rare species. We followed SiqueIRA et al. (2012) to define common and rare species based on the inflection point in a rank abundance curve, i.e., the point in which the curvature change. Species on the left side were

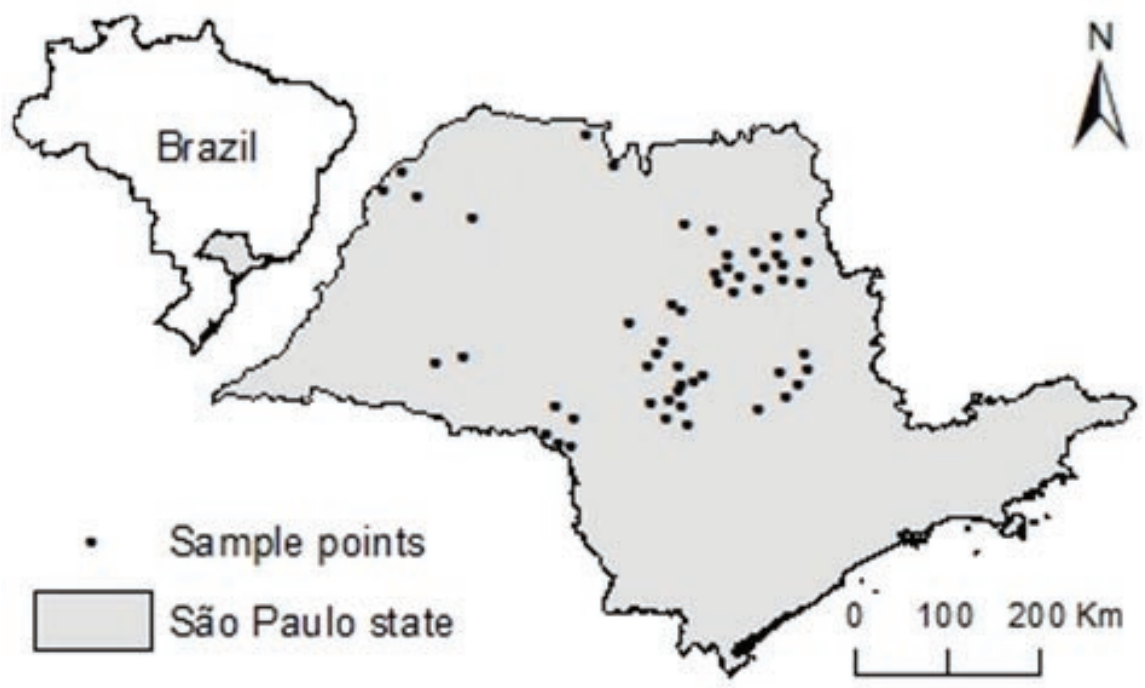

Figure 1. Distribution of cities in the state of São Paulo in which termites were sampled in sugarcane plantations. 
defined as common and those on the right side as rare. This is a straightforward visual method that uses untransformed abundances, stressing the real differences between common and rare species.

Climatic data. We obtained the altitude and macroclimatic variables (Appendix 2) from WorldClim (HiJmans et al. 2005). As they are highly correlated, we performed a Principal Component Analysis (PCA) to reduce the dimensionality. We used the broken stick model to select meaningful principal components (PC, LEGENDRE \& LEGENDRE 2012), which resulted in the retention of two PCs that together explained $85 \%$ of the variation of the data. Then, we calculated the Euclidean distance between PC 1 and PC 2 that will be entered in a Mantel test (see below).

\section{Data Analysis}

Spatial variables. We translated the matrix of site coordinates (latitude and longitude) into spatial predictors using distancebased Moran Eigenvector Maps (dbMEM), formally called Principal Coordinates of Neighbor Matrices (PCNM, Dray et al. 2006, 2012). From a Euclidean pair-wise distance matrix between sampled sites, we computed the threshold value and constructed a truncated distance matrix. This matrix kept distances lower than the threshold unchanged and multiplied those higher by four times the threshold. We then performed a Principal Coordinate Analysis (PCoA) on the truncated distance matrix to obtain eigenvectors that were transformed to a distance matrix to be used as spatial predictors in Mantel tests.

Rank-Dominance curves and species abundance distribution (SADs). We calculated a species accumulation curve (SAC) using the random method, which finds the mean SAC and its standard deviation from random permutations of the data (Gotelli \& Colwell 2001). We built a Species Abundance Distribution (SAD) curve using Whittaker plots, by ranking species (from most to least abundant) in the $x$-axis and their raw abundances in the $y$-axis. Several theoretical models have been suggested to fit observed SADs (reviewed in TOKESHI 1999; MagurRan 2004; McGill et al. 2007). Here, we used the following models: broken stick, Motomura's geometric series, lognormal, Zipf, and ZipfMandelbrot. We used generalized linear (lognormal and Zipf) and nonlinear models (Zipf-Mandelbrot and geometric series) along with the Akaike Information Criteria (AIC) to select the theoretical model that best fitted the observed SAD (WILson 1991).

Partial Mantel test. To test if macroclimatic variables explain the variation in termite species composition, we used a partial Mantel test, which tests the effect of macroclimatic variables (predictor) on species composition while controlling for the effect of spatial variables. A partial Mantel test was used to control for the effect of spatial autocorrelation on species distribution, i.e., the phenomenon by which sites closer to each other have more similar species composition than further ones, regardless of environmental variation (DRAY et al. 2006, 2012; LEGENDRE \& LEGENDRE 2012). Here, we transformed the species composition into a dissimilarity matrix using the Bray-Curtis distance against macroclimatic dissimilarity obtained above, while controlling for the effect of spatial distance (Euclidean distance) (LEGENDRE \& LEGENDRE 2012). The significance of the correlation was estimated by 999 permutations of rows and columns of the species dissimilarity matrix (LEGENDRE \& LEGENDRE 2012). We also made separate Partial Mantel tests using each functional group: woodfeeder, humus-feeder, and grass-litter feeder. We could not run partial Mantel tests for the intermediate group because we found only two species. Analyses were conducted in R (R Core TEam, 2013) packages vegan (OKSANEN et al. 2013) and labdsv (RoBERTs 2013).

\section{RESULTS}

Richness and abundance. We obtained 247 samples, of which 229 (92\%) could be identified. Total species richness was 22 taxa (Table 1). The majority of the taxa (96.51\%) belonged to Termitidae, with higher occurrence frequency of Apicotermitinae (37.12\%) with four morphospecies, followed by Termitinae (30.57\%) with the genera Neocapritermes and Cylindrotermes, and Syntermitinae (27.95\%) with the genera Cornitermes, Syntermes, Embiratermes, Proconitermes, and Silvestritermes. The lowest occurrences (0.87\%) were recorded for the Nasutitermitinae genera Parvitermes and Velocitermes. There was only one species of Rhinotermitidae (3.49\%), Heterotermes sulcatus Mathews.

Our sampling method was efficient to collect species, since the species accumulation curve tended to an asymptote (Figure 2). The species abundance distribution is best fitted by the ZipfMandelbrot model (Figure 3).

Common and rare species. We considered four taxa as common: Neocapritermes opacus Hagen (29.26\%), Apicotermitinae sp.2 (24.89\%), Cornitermes cumulans Kollar (13.10\%), and Apicotermitinae sp.1 (6.99\%). The remaining 18 taxa were considered rare (Figure 4$)$.

Functional groups. The most frequent functional group was humus-feeder (37\%), followed by wood-feeder (34\%), grasslitter feeder (25\%), and intermediate feeders (4\%) (Table 1). We mapped the occurrence frequency of the two most frequent groups by city, showing those that had a frequency of occurrence $\geq$ 50\% in each city (Figure 5, Appendix 3). Of the 53 cities sampled, 16 had predominant occurrence of humus-feeder species and 18 wood-feeder species.

Climatic variables. We found a positive correlation between climate and species composition, independent on the geographic distance $(\mathrm{r}=0.13, P<0.01$, Figure 6). Additionally, climate influenced the distribution of common $(\mathrm{r}=0.11, P<0.01)$, but not rare species $(\mathrm{r}=0.074, P=0.089)$.

We found a low and marginally significant correlation between climate and functional group composition $(\mathrm{r}=0.10, P=0.079)$. However, the composition of humus-feeders $(\mathrm{r}=0.277, P=0.002)$ and grass-litter feeders $(\mathrm{r}=0.158, P=0.03)$ are correlated with the climate when tested separately, contrarily to wood-feeders ( $\mathrm{r}$ $=0.02, P=0.395$ ).

\section{DISCUSSION}

Termite occurrence in sugarcane plantations. We found that the Apicotermitinae (37\%) was the most frequent subfamily of Termitidae, followed by Termitinae (30.57\%), and Syntermitinae (27.95\%). The only species from another family (Rhinotermitidae) was H. sulcatus (3.49\%).

- Subfamily Apicotermitinae: Taxa of this little known subfamily had the highest frequency of occurrence, including Apicotermitinae sp. 1 and 2, which was among the four most common taxa. Most species of this subfamily are humus-feeders that do not build epigean or arboreal nests (CONSTANTINO 1999). Members of this subfamily can be usually found cohabiting nests of other termites species, promoting organic matter decomposition and nutrient cycling (DieHL et al. 2005; CUNHA \& MoRAIS 2010). There are only five genera of this subfamily in South America (Constantino 2002a), of which only Anoplotermes pacificus Müller is considered a pest of Eucalyptus. Also, species of Aparatermes and Grigiotermes are considered pests of rice crops (reviewed in Constantino 2002b). However, most species of this group helps in nutrient cycling and soil aeration, acting as primary consumers and decomposers (LAVELLE et al. 1997; Bignell \& EgGleton 2000; Holt \& Lepage 2000; Davies 2002). Thus, the occurrence of Apicotermitinae in sugarcane plantations seems to be important for the maintenance of soil quality, and the use of insecticides is unnecessary. 


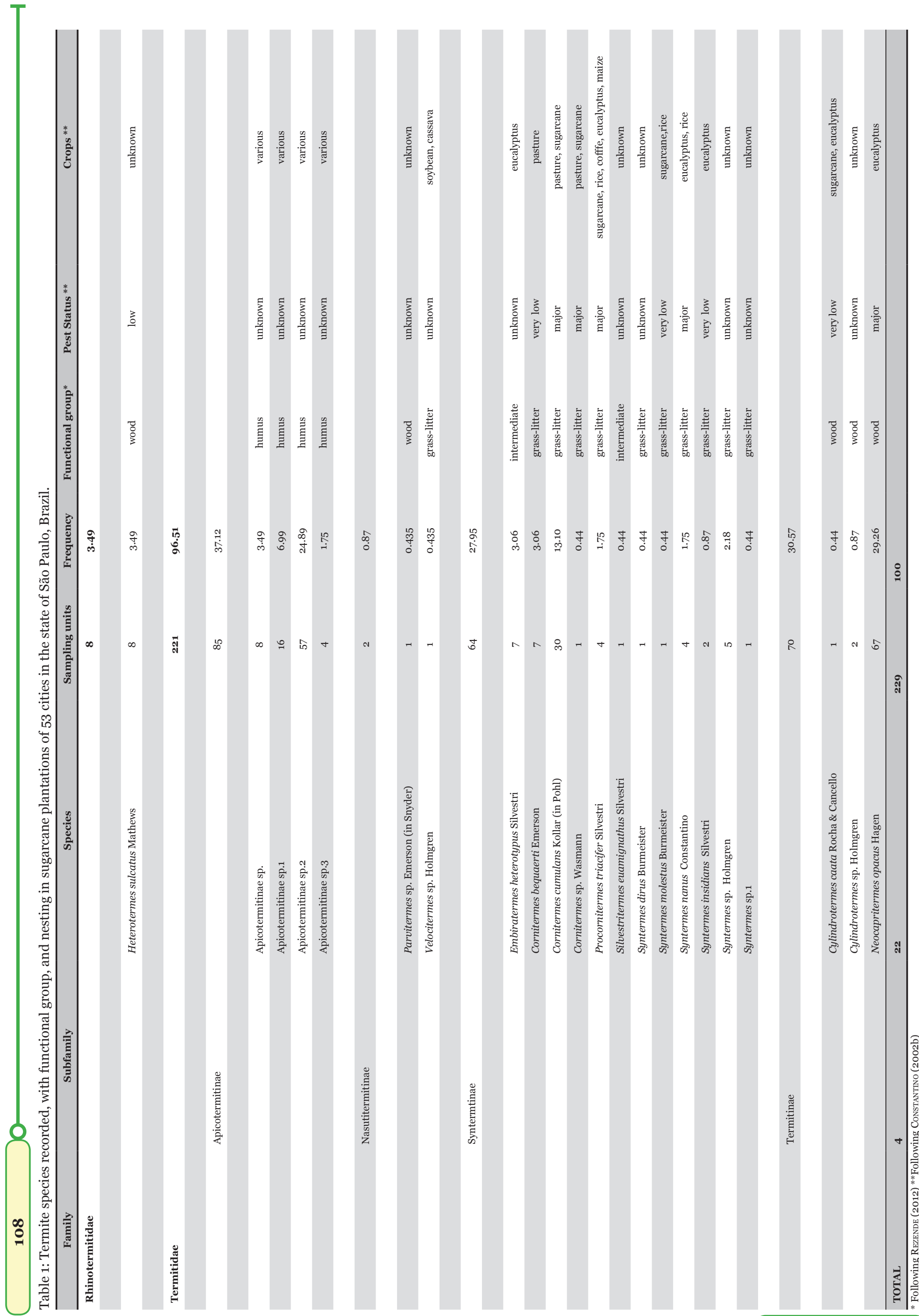




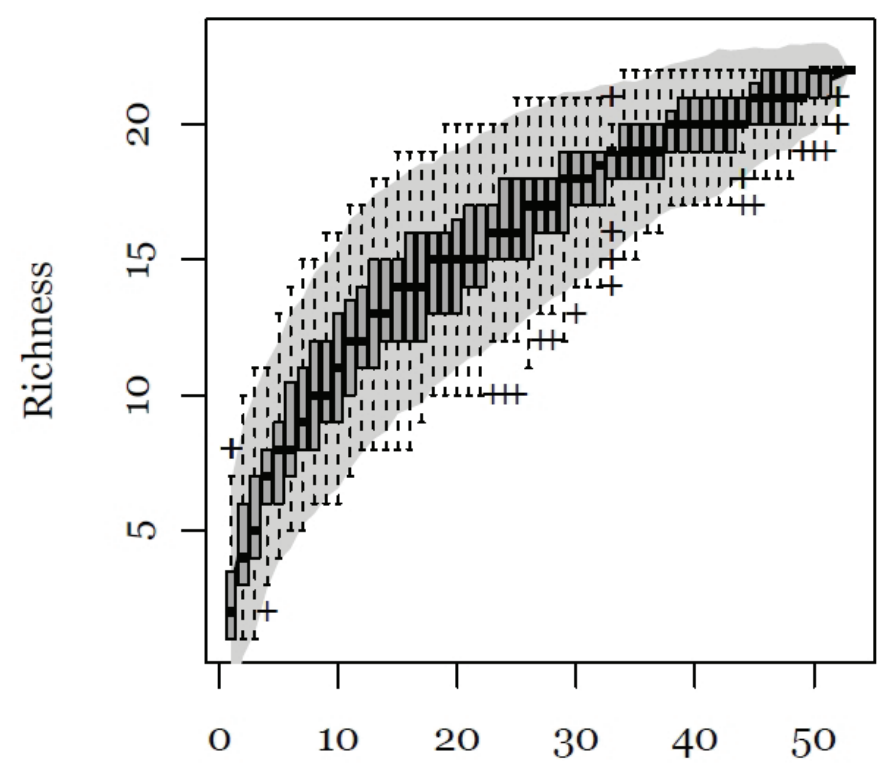

Sites

Figure 2. Mean ( \pm standard deviation) species accumulation curve of termite species collected in sugarcane plantations of 53 cities in the state of São Paulo, Brazil.

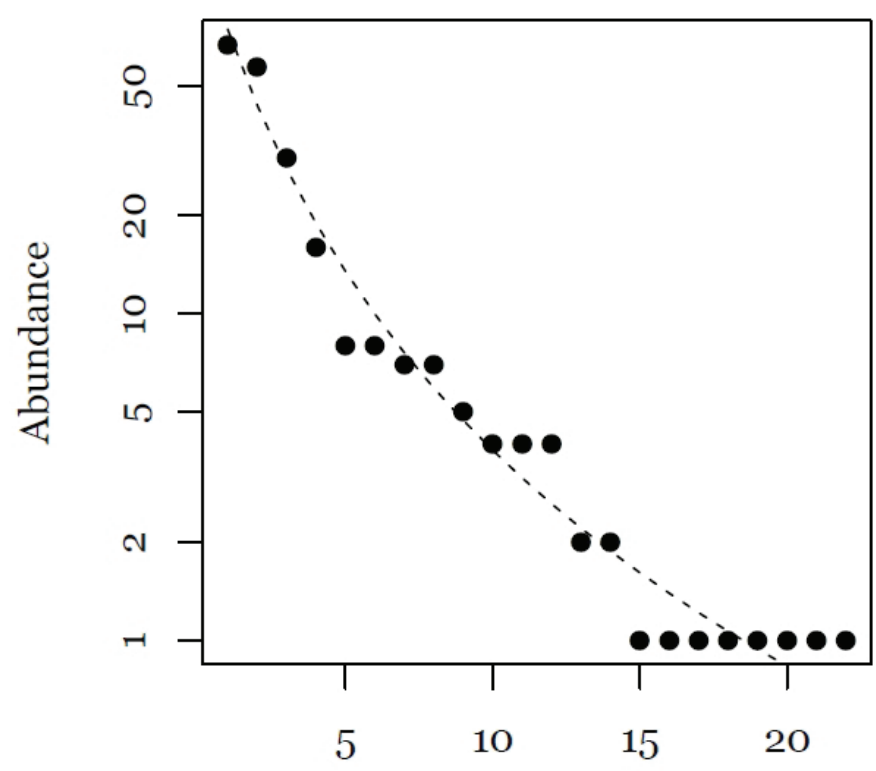

Species rank

Figure 3. Species abundance distribution curve showing a Mandelbrot model distribution of termite species collected in sugarcane plantation in 53 cities of the state of São Paulo, Brazil.

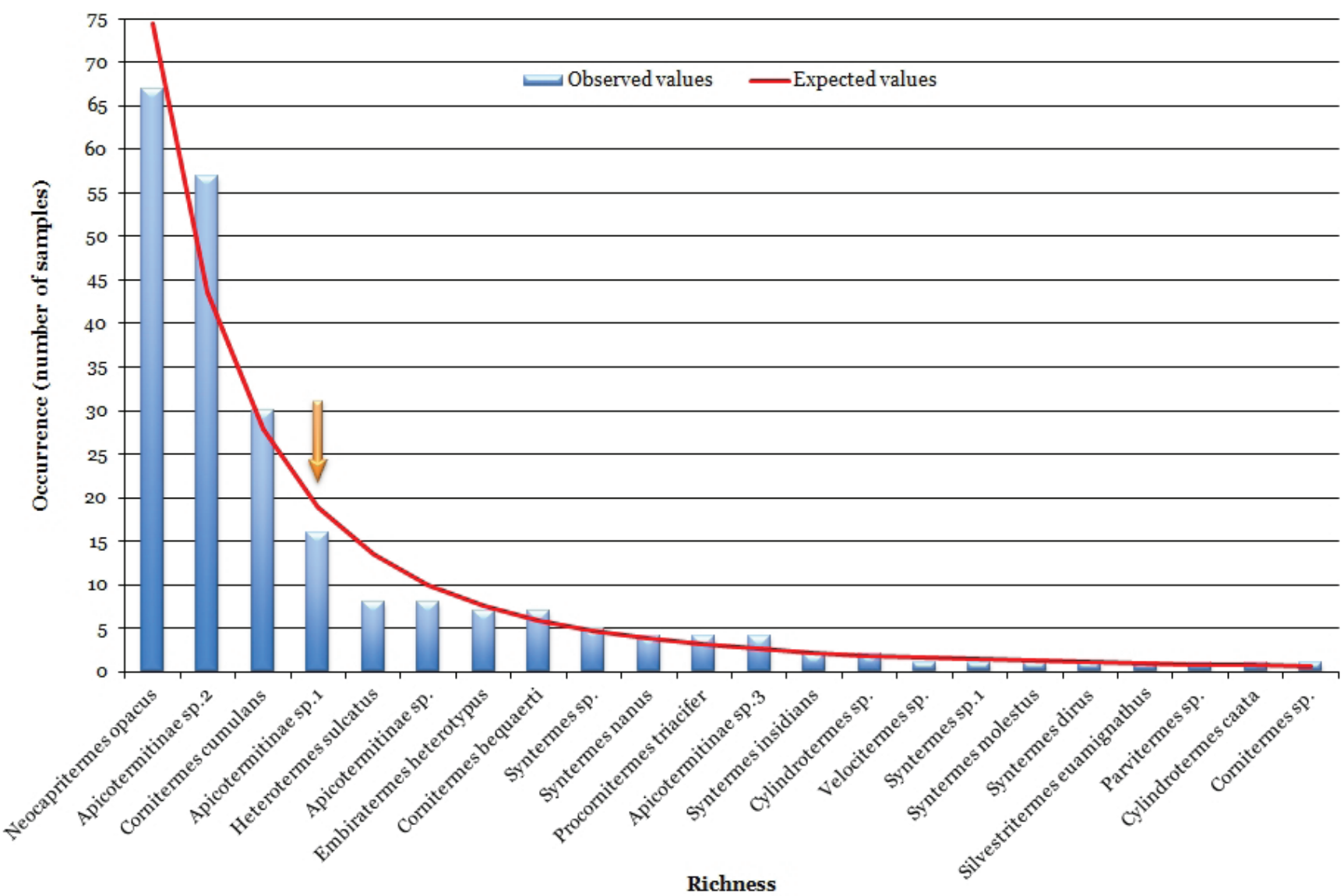

Figure 4. Occurrence of termites (number of samples) in sugarcane plantations in 53 cities of the state of São Paulo. Observed and expected values according to Zipf-Mandelbrot model for the 22 taxa collected. The dashed arrow indicates the inflection point of the curve. Species at the left side were classified as common, and those at the right side were classified as rare.

- Subfamily Termitinae: $N$. opacus (29.26\%) was the most frequent among the common species. This species occurs from Ecuador to eastern Argentina and southern Brazil (KRISHNA \& ARAUJO 1968; ConSTANTINO 1998), it feeds on wood on the floor (Constantino 1999) and is considered a pest in Eucalyptus (reviewed in Constantino 2002b; Contantino 2014) and sugarcane plantations (ChEAvEgatti-Gianotto et al. 2011). Thus, the Brazilian System of Phytosanitary Agrochemicals (AGROFIT 2012) recommends up to
12 possible options chemicals to control this species in sugarcane plantations.

- Subfamily Syntermitinae: C. cumulans was common, with frequency of occurrence of $13.10 \%$. The genus Cornitermes is widely distributed in South America, occurring from the Amazon basin to southern Brazil, extending to Paraguay and northeastern Argentina (Emerson 1952; Constantino 1998). Most species build epigean nests, but some live in 


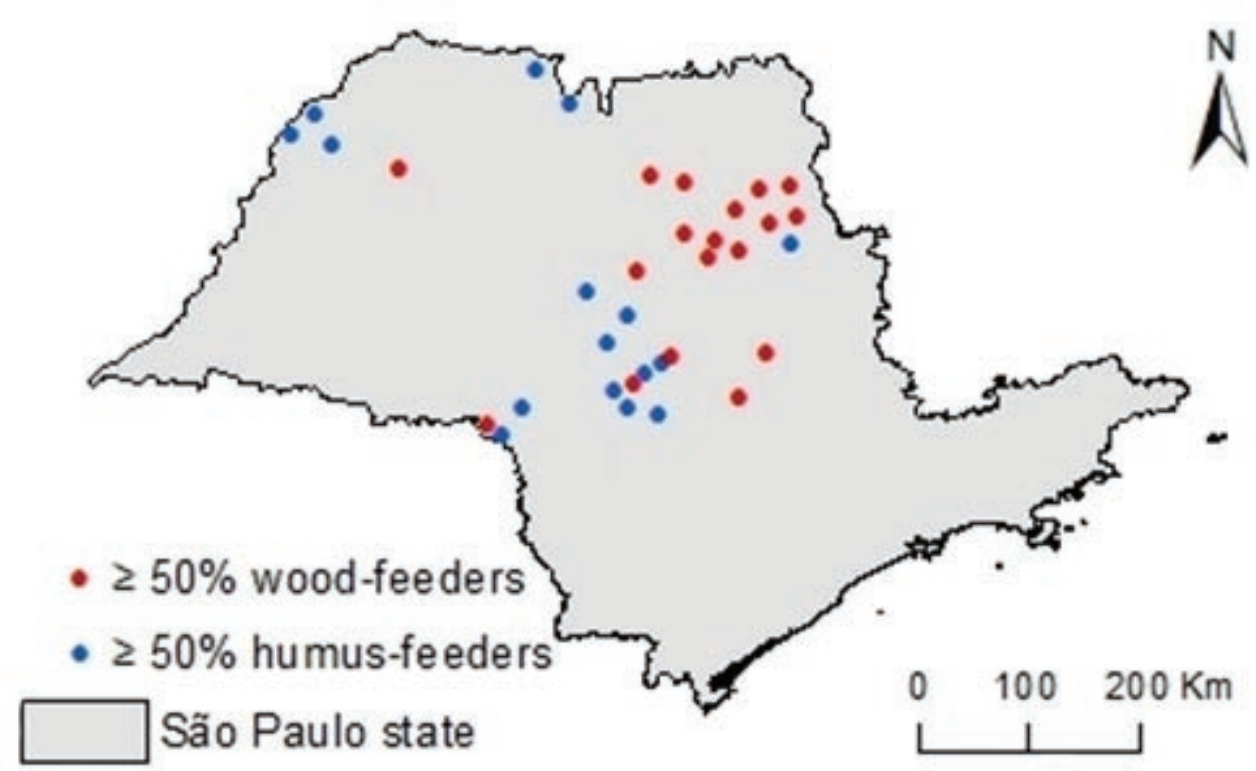

Figure 5. Geographical distribution of cities sampled in the state São Paulo showing the distribution of functional groups of termites, with $\geq 50 \%$ of wood-feeders and humus-feeders.

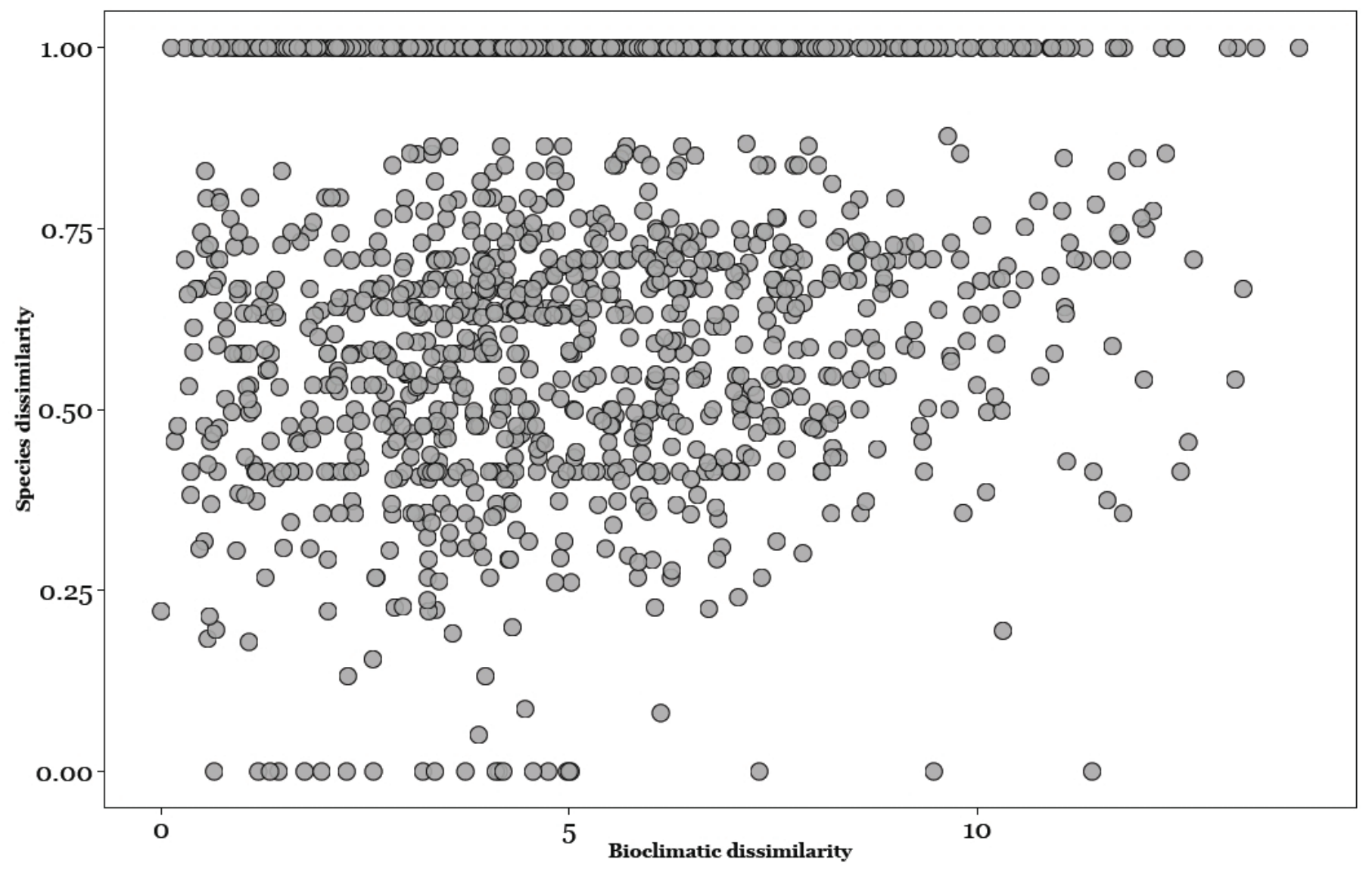

underground nests (Constantino 1999). It feeds on plant material and it is often found in pastures (CZEPAK et al. 2003; CUNHA et al. 2006; VALÉRIO 2006; CARRIJO et al. 2009), which are usually a homogeneous environment with no competitors (Cunha \& Morais 2010). Cornitermes has been suggested to reduce grazing areas for livestock in the Brazilian state of Rio Grande do Sul (DieHl et al. 2005; Fernandes et al. 1998). However, other studies (CZEPAK et al. 2003; ACKERMAN 2007) found that their epigean nests are not harmful, since they do not reduce the grazing area. Nonetheless, this genus is considered a pest in sugarcane plantations (reviewed in Constantino 2002b; Cheavegatti-Gianotto et al. 2011), and whose chemical control is recommended by AGROFIT (2012). Two other genera of this subfamily, Procornitermes and
Syntermes, were rare in this study, although some authors have found that they might be pest in other cultures. Procornitermes occurs from southern Amazon, across Central Brazil and Bolivia to northern Argentina (CANCELLO 1986) and its occurrence seems to be limited by climatic factors in northern South America (EMERSON 1952). However, some species of this genus are considered pests in sugarcane, such as Proconitermes triacifer Silvestri (CheavegattiGianotto et al. 2011; AGROFIT 2012; Costantino 2002b) and Proconitermes striatus (Hagen) (AGROFIT 2012). The genus Syntermes of the same subfamily was considered rare in this study. It occurs from northern South America to northern and northeastern Argentina, east of the Andes (Constantino 1998) and feeds mainly on litter, being 
considered a pest in sugarcane, Eucalyptus, rice plantations, and pastures (reviewed in CosnTANTino 2002b). A previous study (Miranda et al. 2004) recorded Syntermes nanus Constantino in sugarcane plantations in northeastern Brazil. However, the frequency of leaves attack does not cause significant losses.

- Family Rhinotermitidae: The only Rhinotermitidae species recorded by us was $H$. sulcatus, which had a low occurrence frequency and was considered rare. The genus Heterotermes occurs from southern Mexico, including the Bahamas and West Indies, to northern Argentina, but $H$. tenuis has a wide distribution throughout South America (CONSTANTINO 1998, 2001). It feeds on living or dead plant material, having been considered pest in several crops, mainly sugarcane and timber (Haifig et al. 2008). A previous study in São Paulo (Almeida \& Alves 1999) considered H. tenuis as the main pest in sugarcane plantations due to its wide distribution and high abundance. The estimated damage caused by this species can reach US\$ 500/ha (GARCIA 2004), including chemical control, for which up to 42 possible options chemicals can be used (AGROFIT 2012). The low occurrence frequency of $H$. sulcatus we found (3.5\%) may indicate a decline in its abundance due to the continuous use of insecticides over the last decade, which is interesting for commercial crops.

The remaining 18 taxa of termites collected in the sugarcane plantations of São Paulo and to samples were categorized as rare. However, we suggest that termite regional fauna should be maintained. According to Oliveira \& DeL-Claro (2005) and Del-Claro (2008) interspecific ecological relationships and overlapping of niches are important for the maintenance of populations at low levels. CARRIJO et al. (2009) showed that habitat simplification in the "Cerrado" led to extinction of termite populations as well as other members of the fauna and flora for the loss of specific features due to the application of pesticides. According to Singh \& SingH (2001) the abundance and composition of termite's community respond differently to environments and insecticide use.

The influence of climatic variables on termite occurrence in sugarcane plantations. Environmental variables, such as altitude, temperature, and rainfall, besides local vegetation structure and complexity influence termite communities (CoLLINs 1980; GATHORNE-HARDy et al. 2001; DAvies 2002; InOUE et al. 2006; Jones \& EGGLETON 2011). However, it is difficult to generalize distribution patterns of termites in South America (Jones \& EGGLETON 2011), because collections and studies are concentrated on a few regions of Guyana and Brazil, especially Amazonia, São Paulo, and Mato Grosso. Furthermore, a previous study (DieHL et al. 2014) suggests a positive relationship between species occurrence and altitude in different geomorphological regions of Rio Grande do Sul state in southern Brazil. However, their results were inconclusive due to the low number of collections in the state.

Here, climate variables influenced the distribution of four common taxa: $N$. opacus (wood-feeder), Apicotermitinae sp. 1 and 2 (humus-feeder), and C. cumulans (grass-litter feeder), but none of the 18 rare taxa. However, only humus-feeders and grass-litter feeders were affected when we tested the influence of climatic variables on functional groups. Wood-feeders were not affected and intermediates were not tested due to low sample size.

There are many controversies about functional group classification of $N$. opacus. It was considered here a wood-feeder, but it has been defined as intermediate feeder by Constantino (2002), woodfeeder by REzende (2012), and wood/humus-feeder by Souza et al. (2012). This species has been found feeding on trees, trunks and roots, with soil nests in the Brazilian Cerrado (Mathews 1977). Some authors (e.g., Sleaford et al. 1996; Donovan et al. 2001) suggest that termite diet is distributed along a gradient of humification, from living timber to humus. This could explain the assignment of $N$. opacus to different functional groups, especially because the species behavior in some studies cited was based on field observations. Additionally, this would explain why the distribution of this species here was influenced by environmental variables, when tested along with rare species, when the reverse was true when tested clumped with wood-feeders.

A previous study (AcKeRman et al. 2009) found a high frequency of occurrence of humus-feeders (57\%) in less diverse agroforests and primary forests in Central Amazonia, suggesting that the ability of agroforests to support populations of humus-feeders could potentially have a positive effect on soil fertility in agroecosystems. Conversely, Miranda et al. (2004) did not record humus-feeders in a sugarcane plantation in Northeastern Brazil.

Another study (PALIN et al. 2011) along an Amazon-Andes altitudinal gradient in Peru found that the diversity declined with increased elevation. However, functional groups responded differently to the upper distribution limit. For example, the distribution limit for humus-feeders was between 925 and 1,500 $\mathrm{m}$ asl, while for wood-feeders it was between 1,550 and 1,850 $\mathrm{m}$ asl. This pattern suggested that energy requirements of each group are a key factor shaping species occurrence associated with altitude and temperature.

The model that best fitted the species abundance distribution was Zipf-Mandelbrot. Following WILSON (1991) the presence of a species in this model depends on the previous physical condition and previous species presence. Specifically, pioneer species, requiring little previous conditions. Late successional species need more energy, time, and organization of the ecosystem before they can invade, justifying why these species are rare. These differences between pioneer and late successional species give a Zipf-Mandelbrot distribution.

Finally, it seems that continued use of insecticides had possibly reduced the abundance of some pest species, which are now rare, such as those of the genus Heterotermes. Contrarily to other studies, our results suggest that most termite species recorded is potentially beneficial for sugarcane plantations, given the high incidence of humus-feeders. We then reinforce the importance of associating ecology research to agricultural systems and pest control methods and suggest an in-depth Integrated Pest Management (IPM) analysis based on data on damage/injury coupled with cost/benefits of control. 
T Appendix 1. Geographic coordinates of the cities with sugarcane plantations sampled in the state of São Paulo.

\begin{tabular}{|c|c|c|c|}
\hline City & Geographic coordinates & City & Geographic coordinates \\
\hline Altinópolis & $21^{\circ} 01^{\prime} 33^{\prime \prime S} ; 47^{\circ} 22^{\prime} 26^{\prime \prime} \mathrm{W}$ & Luís Antônio & $21^{\circ} 33^{\prime} 18^{\prime \prime S} ; 47^{\circ} 42^{\prime} 14^{\prime \prime} \mathrm{W}$ \\
\hline Araras & $22^{\circ} 21^{\prime} 25^{\prime \prime} \mathrm{S} ; 47^{\circ} 23^{\prime} \mathrm{O} 2^{\prime \prime} \mathrm{W}$ & Mineiros do Tietê & $22^{\circ} 24^{\prime} 32^{\prime \prime} \mathrm{S} ; 4^{\circ} 27^{\prime} \mathrm{O} 3^{\prime \prime} \mathrm{W}$ \\
\hline Areiópolis & $22^{\circ} 40^{\prime} 04^{\prime \prime S} ; 48^{\circ} 39^{\prime} 54^{\prime \prime} \mathrm{W}$ & Motuca & $21^{\circ} 30^{\prime} 28^{\prime \prime} \mathrm{S} ; 48^{\circ} \mathrm{Og} \mathrm{O}^{\prime} \mathrm{O} 3^{\prime \prime} \mathrm{W}$ \\
\hline Bariri & $22^{\circ} 04^{\prime} 26^{\prime \prime S} ; 48^{\circ} 44^{\prime} 24^{\prime \prime} \mathrm{W}$ & Nova Europa & $21^{\circ} 46^{\prime} 40^{\prime \prime} \mathrm{S} ; 4^{\circ} 33^{\prime} 39^{\prime \prime} \mathrm{W}$ \\
\hline Barra Bonita & $22^{\circ} 29^{\prime} 42^{\prime \prime} \mathrm{S} ; 48^{\circ} 33^{\prime} 28^{\prime \prime} \mathrm{W}$ & Ourinhos & $22^{\circ} 58^{\prime} 44^{\prime \prime} \mathrm{S} ; 49^{\circ} 52^{\prime} 15^{\prime \prime} \mathrm{W}$ \\
\hline Barrinha & $21^{\circ} 11^{\prime} 38^{\prime \prime} \mathrm{S} ; 48^{\circ} 09^{\prime} 5 \mathrm{o}^{\prime \prime} \mathrm{W}$ & Paulo de Faria & $20^{\circ} 01^{\prime} 51^{\prime \prime} \mathrm{S} ; 49^{\circ} 22^{\prime} 58^{\prime \prime} \mathrm{W}$ \\
\hline Bebedouro & $20^{\circ} 56^{\prime} 56^{\prime \prime} \mathrm{S} ; 48^{\circ} 28^{\prime} 44^{\prime \prime} \mathrm{W}$ & Pederneiras & $22^{\circ} 21^{\prime} \mathrm{O} 7^{\prime \prime} \mathrm{S} ; 48^{\circ} 46^{\prime} 3 \mathrm{O}^{\prime \prime} \mathrm{W}$ \\
\hline Boraceia & $22^{\circ} 11^{\prime} 34^{\prime \prime} \mathrm{S} ; 48^{\circ} 46^{\prime} 44^{\prime \prime} \mathrm{W}$ & Pereira Barreto & $20^{\circ} 38^{\prime} 16^{\prime \prime} \mathrm{S} ; 51^{\circ} \mathrm{O} 6^{\prime} 32^{\prime \prime} \mathrm{W}$ \\
\hline Botucatu & $22^{\circ} 53^{\prime} \mathrm{O9} 9^{\prime \prime} \mathrm{S} ; 4^{\circ} 26^{\prime} 42^{\prime \prime} \mathrm{W}$ & Piracicaba & $22^{\circ} 43^{\prime} 30^{\prime \prime} \mathrm{S} ; 47^{\circ} 38^{\prime} 56^{\prime \prime} \mathrm{W}$ \\
\hline Brodósqui & $20^{\circ} 59^{\prime} 27^{\prime \prime} \mathrm{S} ; 47^{\circ} 39^{\prime} 32^{\prime \prime} \mathrm{W}$ & Pitangueiras & $21^{\circ} \mathrm{Oo} 322^{\prime \prime S} ; 48^{\circ} 13^{\prime} 19^{\prime \prime} \mathrm{W}$ \\
\hline Cajuru & $21^{\circ} 16^{\prime} 30^{\prime \prime} \mathrm{S} 47^{\circ} 18^{\prime} 14^{\prime \prime} \mathrm{W}$ & Pradópolis & $21^{\circ} 21^{\prime} 32^{\prime \prime} \mathrm{S} ; 48^{\circ} \mathrm{O} 3^{\prime} 57^{\prime \prime} \mathrm{W}$ \\
\hline Chavantes & $23^{\circ} \mathrm{O} 2^{\prime} 20^{\prime \prime} \mathrm{S} ; 49^{\circ} 42^{\prime} 32^{\prime \prime} \mathrm{W}$ & Pratânia & $22^{\circ} 48^{\prime} 28^{\prime \prime} \mathrm{S} ; 48^{\circ} 39^{\prime} 57^{\prime \prime} \mathrm{W}$ \\
\hline Cordeirópolis & $22^{\circ} 28^{\prime} 55^{\prime \prime} \mathrm{S} ; 47^{\circ} 27^{\prime} 25^{\prime \prime} \mathrm{W}$ & Quatá & $22^{\circ} 14^{\prime} 52^{\prime \prime} \mathrm{S} ; 50^{\circ} 41^{\prime} 52^{\prime \prime} \mathrm{W}$ \\
\hline Cravinhos & $21^{\circ} 20^{\prime} 24^{\prime \prime} \mathrm{S} ; 47^{\circ} 43^{\prime} 44^{\prime \prime} \mathrm{W}$ & Rancharia & $22^{\circ} 13^{\prime} 44^{\prime \prime} \mathrm{S} ; 50^{\circ} 53^{\prime} 34^{\prime \prime} \mathrm{W}$ \\
\hline Dois Córregos & $22^{\circ} 21^{\prime} 57^{\prime \prime} \mathrm{S} ; 48^{\circ} 22^{\prime} 48^{\prime \prime} \mathrm{W}$ & Ribeirão Preto & $21^{\circ} 10^{\prime} 40^{\prime \prime} \mathrm{S} ; 47^{\circ} 48^{\prime} 36^{\prime \prime} \mathrm{W}$ \\
\hline Guariba & $21^{\circ} 21^{\prime} 36^{\prime \prime} \mathrm{S} ; 48^{\circ} 13^{\prime} 4 \mathrm{O}^{\prime \prime} \mathrm{W}$ & Rincão & $21^{\circ} 35^{\prime} 13^{\prime \prime S} ; 4^{\circ} 04^{\prime} 15^{\prime \prime} \mathrm{W}$ \\
\hline Guatapará & $21^{\circ} 29^{\prime} 49^{\prime \prime} \mathrm{S} ; 48^{\circ} \mathrm{O} 2^{\prime} 16^{\prime \prime} \mathrm{W}$ & Rio Claro & $22^{\circ} 24^{\prime} 39^{\prime \prime} \mathrm{S} ; 47^{\circ} 33^{\prime} 39^{\prime \prime} \mathrm{W}$ \\
\hline Iacanga & $21^{\circ} 53^{\prime} 24^{\prime \prime} \mathrm{S} ; 4^{\circ} 9^{\circ} 1^{\prime} 3 \mathrm{O}^{\prime \prime} \mathrm{W}$ & Santa Cruz do Rio Pardo & $22^{\circ} 53^{\prime} 56^{\prime \prime} \mathrm{S} ; 4^{\circ} 9^{\circ} 37^{\prime} 58^{\prime \prime} \mathrm{W}$ \\
\hline Icém & $20^{\circ} 20^{\prime} 31^{\prime \prime S} ; 49^{\circ} 11^{\prime} 42^{\prime \prime} \mathrm{W}$ & Santa Rosa do Viterbo & $21^{\circ} 28^{\prime} 22 " \mathrm{~S} ; 47^{\circ} 21^{\prime} 46^{\prime \prime} \mathrm{W}$ \\
\hline Igaraçu do Tietê & $22^{\circ} 30^{\prime} 32^{\prime \prime} \mathrm{S} ; 48^{\circ} 33^{\prime} 28^{\prime \prime} \mathrm{W}$ & Santo Antônio da Alegria & $21^{\circ} \mathrm{O} 5^{\prime} 13^{\prime \prime S} ; 47^{\circ} \mathrm{Og}{ }^{\prime} \mathrm{O} 3^{\prime \prime} \mathrm{W}$ \\
\hline Ilha Solteira & $22^{\circ} 30^{\prime} 32^{\prime \prime} \mathrm{S} ; 48^{\circ} 33^{\prime} 28^{\prime \prime} \mathrm{W}$ & São Manuel & $22^{\circ} 43^{\prime} 51^{\prime \prime} \mathrm{S} ; 4^{\circ} 34^{\prime} 15^{\prime \prime} \mathrm{W}$ \\
\hline Ipaussu & $23^{\circ} \mathrm{O} 3^{\prime} 25^{\prime \prime S} ; 49^{\circ} 37^{\prime} 33^{\prime \prime} \mathrm{W}$ & São Pedro Turvo & $22^{\circ} 44^{\prime} 49^{\prime \prime} \mathrm{S} ; 49^{\circ} 44^{\prime} 24^{\prime \prime} \mathrm{W}$ \\
\hline Iracemápolis & $22^{\circ} 34^{\prime} 51^{\prime \prime} \mathrm{S} ; 47^{\circ} 31^{\prime} \mathrm{O} 8^{\prime \prime} \mathrm{W}$ & São Simão & $21^{\circ} 28^{\prime} 44^{\prime \prime} \mathrm{S} ; 47^{\circ} 33^{\prime} \mathrm{O} 3^{\prime \prime} \mathrm{W}$ \\
\hline Itapura & $20^{\circ} 38^{\prime} 45^{\prime \prime S} ; 51^{\circ} 30^{\prime} 32^{\prime \prime} \mathrm{W}$ & Serra Azul & $21^{\circ} 18^{\prime} 39^{\prime \prime} \mathrm{S} ; 47^{\circ} 33^{\prime} 57^{\prime \prime W}$ \\
\hline Jaú & $22^{\circ} 17^{\prime} 45^{\prime \prime} \mathrm{S} ; 48^{\circ} 33^{\prime} 28^{\prime \prime} \mathrm{W}$ & Serrana & $21^{\circ} 12^{\prime} 39^{\prime \prime} \mathrm{S} ; 47^{\circ} 35^{\prime} 45^{\prime \prime} \mathrm{W}$ \\
\hline Leme & $22^{\circ} 11^{\prime} 09^{\prime \prime S} ; 47^{\circ} 23^{\prime} 24^{\prime \prime} \mathrm{W}$ & Tabatinga & $21^{\circ} 43^{\prime} \mathrm{O} 1^{\prime \prime S} ; 48^{\circ} 41^{\prime} 16^{\prime \prime} \mathrm{W}$ \\
\hline Lençóis Paulista & $22^{\circ} 35^{\prime} 56^{\prime \prime} \mathrm{S} ; 48^{\circ} 48^{\prime} \mathrm{oo}$ "W & & \\
\hline
\end{tabular}

Appendix 2. List of macroclimatic variables obtained from World Clim (http://www.worldclim.org)

\begin{tabular}{ll}
\hline & \\
\hline BIO1 & Mnnual Mean Temperature \\
\hline BIO2 & Mean Diurnal Range (Mean of monthly (max temp - min temp)) \\
\hline BIO3 & Isothermality (BIO2/BIO7) ${ }^{*}$ 100) \\
\hline BIO4 & Temperature Seasonality (standard deviation *100) \\
\hline BIO5 & Max Temperature of Warmest Month \\
\hline BIO6 & Min Temperature of Coldest Month \\
\hline BIO7 & Temperature Annual Range (BIO5-BIO6) \\
\hline BIO8 & Mean Temperature of Wettest Quarter \\
\hline BIO10 & Mean Temperature of Driest Quarter \\
\hline BIO11 & Mean Temperature of Warmest Quarter \\
\hline BIO12 & Annual Precipitation \\
\hline BIO13 & Precipitation of Wettest Month \\
\hline BIO14 & Precipitation of Driest Month \\
\hline BIO15 & Precipitation Seasonality (Coefficient of Variation) \\
\hline BIO16 & Precipitation of Wettest Quarter \\
\hline BIO17 & Precipitation of Driest Quarter \\
\hline BIO18 & Precipitation of Warmest Quarter \\
\hline BIO19 & Precipitation of Coldest Quarter \\
\hline & \\
\hline
\end{tabular}


Appendix 3. Cities in the states of São Paulo, Brazil, whose sugarcane plantations had a frequency of occurrence $\geq 50 \%$ for humus-feeders and woodfeeders.

\begin{tabular}{|c|c|}
\hline \multicolumn{2}{|c|}{ Frequency of occurrence of functional groups of termites } \\
\hline$\geq 50 \%$ humus-feeders & $\geq 50 \%$ wood-feeders \\
\hline & Altinópolis \\
\hline Bariri & Areiopólis \\
\hline Botucatu & Bebedouro \\
\hline Chavantes & Brodósqui \\
\hline Iacanga & Cajurú \\
\hline Icem & Dois Córregos \\
\hline Igaraçú do Tietê & Guariba \\
\hline Ilha Solteira & Guatapara \\
\hline Itapura & Luis Antônio \\
\hline Lençóis Paulista & Ourinhos \\
\hline Mineiros do Tietê & Piracicaba \\
\hline Paulo de Faria & Pitangueiras \\
\hline Pederneiras & Ribeirão Preto \\
\hline Pereira Barreto & Rincão \\
\hline Pratânia & Rio Claro \\
\hline Santa Cruz do Rio Pardo & Santo Antônio da Alegria \\
\hline Santa Rosa do Viterbo & Serra Azul \\
\hline & Tabatinga \\
\hline
\end{tabular}

\section{ACKNOWLEDGMENTS}

We would like to thank "Pontifícia Universidade Católica de Campinas" for providing working space and research grants. "Centro de Tecnologia Canavieira" and the plantation owners allowed access to their land. Technicians helped in fieldwork and undergrad biology students from "PUC-Campinas" helped in sample sorting. SISBIO provided collecting license (\#12205-1). People from "Laboratório de Isoptera of the Museu de Zoologia of the Universidade de São Paulo" (MZUSP), especially Dr. Eliana M. Cancello and Dr. Maurício M. Rocha, helped with species identification. Thiago Gonçalves-Souza provided useful statistical advice and commented on a previous version of this manuscript. Diogo B. Provete reviewed the English language. Elena Diehl critically read the first draft.

\section{REFERENCES}

Ackerman, I.L., W.G. Teixeira, S.J. Riha, J. Lehmann. \& E.C.M. Fernandes 2007. The impact of mound-building termites on surface soil properties in a secondary forest of Central Amazonia. Applied Soil Ecology, 37: 267-276. doi: 10.1016/j. apsoil.2007.08.005.

Ackerman, I.L., R. Constantino, H.G.Jr. Gauch, J. Lehmann, S.J. Riha \& E.C.M. Fernandes, 2009. Termite (Insecta: Isoptera) species composition in a primary rain forest and agroforests in Central Amazonia. Biotropica, 41: 226-233. doi: 10.1111/ j.1744-7429.2008.00479.x.

AGROFIT, 2012. Sistemas de agrotóxicos fitossanitários. Available on: <http://extranet.agricultura.gov.br/agrofit cons/principal agrofit cons> [Acessed on: 06.21. 2012].

Almeida, J.E.M. \& S.B. Alves, 1999. Controle de Heterotermes tenuis (Hagen, 1858) (Isoptera: Rhinotermitidae) em canade-açúcar com iscas TERMITRAP ${ }^{\circledR}$ associadas ao fungo entomopatogênico Beauveria bassiana (Bals.) Vuill. e/ou a inseticidas em época de seca. Arquivos do Instituto Biológico, 66: 85-90.

Araújo, R.L., 1977. Catálogo dos Isoptera do Novo Mundo. Rio de Janeiro: Academia Brasileira de Ciências, 92 p.

Arrigoni, E.D.B., Precetti, A.A.C.M., Almeida, L.C. \& P. Kasten Junior, 1988. Metodologia de levantamento de pragas de solo em cana-de-açúcar. In: Seminário de Tecnologia Agronômica Copersucar, 4, Anais, Piracicaba, SP. 1988. 647-655.

Bandeira, A.G. \& A. Vasconcellos, 2002. A quantitative survey of termites in a gradient of disturbed highland forest in Northeastern Brazil (Isoptera). Sociobiology, 39: 429-439.

Bandeira, A.G., A. Vasconcellos, M.P. Silva, \& R. Constantino, 2003. Effects of habitat disturbance on the termite fauna in a highland humid forest in the Caatinga domain, Brazil. Sociobiology, 42: 117-127.

Batista-Pereira, L.G., M.G. Santos, A.G. Correa, J.B. Fernandes, A. Arab, A.M Costa-Leonardo, C.R. Dietrich, D.A. Pereira, \& O.C. Bueno, 2004. Cuticular hydrocarbons of Heterotermes tenuis (Isoptera: Rhinotermitidae): analyses and electrophysiological studies. Zeitschrift fur Naturforschung, 59: 135-139.

Berti Filho, E., 1995. Cupins e florestas, p. 127-140. In: Berti Filho, E. \& L.R. Fontes (Eds), Alguns aspectos atuais da biologia e controle de cupins. Piracicaba: FEALQ. 183 p.

Bignell, D.E. \& P. Eggleton, 200o. Termites in ecosystems, p. 363387. In: T. Abe, D.E. Bignell \& M. Higashi (Eds.), Termites: Evolution, Sociality, Symbioses, Ecology. Netherlands: Kluwer Academic Publishers. 466 p.

Campos, M.B.S., S.B. Alves \& N. Macedo, 1998. Seleção 
de iscas celulósicas para o cupim Heterotermes tenuis (Isoptera: Rhinotermitidae) em cultura de cana-de-açúcar. Scientia Agricola, 55: 480-484. doi: 10.1590/So10390161998000300017.

Cancello, E.M., 1986. Revisão de Procornitermes Emerson (Isoptera, Termitidae, Nasutitermitinae). Papéis Avulsos de Zoologia, 36: 189-236.

Cancello, E.M., 1989. Revisão de Cornitermes Wasmann (Isoptera, Termitidae, Nasutitermitinae). Dissertação (Mestrado - PPG em Ciências Biológicas) - Universidade de São Paulo, 151 p.

Carrijo, T.F., d. Brandão, D.E. Oliveira, D.A. Costa \& T. Santos, 2009. Effects of pasture implantation on the termite (Isoptera) fauna in the Central Brazilian savanna (Cerrado). Journal of Insect Conservation, 13: 575-581. doi: 10.1007/s10841-0089205-y.

Cheavegatti-Gianotto, A., H.M.C. Abreu, P.Arruda, J.C. Bespalhok Filho, W.L. Burnquist, S. Creste, LDi. Ciero, J.A. Ferro, A.V.O. Figueira, T.S. Filgueiras, M.F. Grossi-De-Sá, E.C. Guzzo, H.P. Hoffmann, M.G.A. Landell, N. Macedo, S. Matsuoka, F.C. Reinach, E. Romano, W.J. Silva, M.C. Silva Filho \& E.C. Ulian, 2011. Sugarcane (Saccharum X officinarum): a reference study for the regulation of genetically modified cultivars in Brazil. Tropical Plant Biology, 4: 62-89. doi: 10.1007/s12042-011-9068-3

Collins, N.M., 1980. The distribution of soil macrofauna on the west ridge of Gunung (Mount) Mulu, Sarawak. Oecologia 44: 263-275. doi: 10.1007/BFo0572689.

Collins, N.M., 1981. The role of termites in the decomposition of wood and leaf litter in the southern Guinea Savanna of Nigeria. Oecologia, 51: 389-399. doi: 10.1007/BF00540911.

CONAB Companhia Nacional de Abastecimento. 2009. Available on: <http://www.conab.gov.br> Access on: [06.20.2011].

Constantino R., 1994. A new genus of Nasutitermitinae with mandibulate soldiers from tropi- cal North America (Isoptera: Termitidae). Sociobiology, 25: 285-294.

Constantino, R., 1995. Revision of the neotropical termite genus Syntermes Holmgren (Isoptera: Termitidae). The University of Kansas Science Bulletin, 55: 455-518.

Constantino, R., 1998. Catalog of the living termites of the new world (Insecta: Isoptera). Arquivos de Zoologia, 35: 135-26o. doi: 10.11606/issn.2176-7793.v35i2p135-230.

Constantino, R., 1999. Chave ilustrada para identificação dos gêneros de cupins (Insecta: Isoptera) que ocorrem no Brasil. Papéis Avulsos de Zoologia, 40: 387-448.

Constantino, R., 2001. Key to the soldiers of South American Heterotermes with a new species from Brazil (Isoptera: Rhinotermitidae). Insect Systematics and Evolution, 31: 463472. doi: 10.1163/187631200X00499.

Constantino, R., 2002a. An illustrated key to Neotropical termite genera (Insecta: Isoptera) based primarily on soldiers. Zootaxa, 67: 1-40.

Constantino, R., 2002b. The pest termites of South America: taxonomy, distribution and status. Journal of Applied Entomology, 126: 355-365. doi: 10.1046/j.14390418.2002.00670.x.

Constantino, R., 2014. On-line termite database. Available on: <http://164.41.140.9/catal >. Access on: [06.20.2014].

Contantino, R., A.N.S. Acioli, K. Schmidt, C. Cuezzo, S.H.C. Carvalho \& A. Vasconcello, 2006. A taxonomic revision on the Neotropical termite genera Labiotermes Holmgren and Paracornitermes Emerson (Isoptera: Termitidae: Nasutitermitinae). Zootaxa, 1340: 1-44.

Constantino, R. \& S.H.C. Carvalho, 2011. Paracurvitermes, a new genus of Syntermitinae (Isoptera: Termitidae). Sociobiology, 57: 377-388.

Cunha, H.F., D.A. Costa \& D. Brandão, 2006. Termite (Isoptera) assemblages in some regions of the Goiás State, Brazil. Sociobiology, 47: 505-518.

Cunha, H.F. \& P.P.A.M. Morais, 2010. Relação espécie-área em cupinzeiros de pastagem, Goiânia-GO, Brasil. Entomobrasilis,
3: 60-63.

Czepak, C., E.A. Araujo \& P.M. Fernandes, 2003. Ocorrência de espécies de cupins de montículo em pastagens no Estado de Goiás. Pesquisa Agropecuária Tropical, 33: 35-38.

Dantas, F., 2011. Hora de Renovar. CANAL: Jornal da Bioernegia. Goiânia, GO, maio de 2011, ano 5, n. 56: 18-21.

Davies, R.G., 2002. Feeding group responses of a Neotropical termite assemblage to rain forest fragmentation. Oecologia, 133: 233-242. doi: 10.1007/s00442-002-1011-8.

De Souza, O.F.F. \& Brown, V.K. (1994). Effects of habitat fragmentation on Amazonian termite communities. Journal of Tropical Ecology, 10: 197-206. doi: 10.1017/ S0266467400007847.

Del-Claro, K., 2008. Biodiversidade Interativa: a ecologia comportamental e de interações como base para o entendimento das redes tróficas que mantém a viabilidade das comunidades naturais, p. 599-614. In: Seixas J. \& J. Cerasoli (Eds.), UFU, ano 30 - Tropeçando Universos (artes, humanidades, ciências). Uberlândia: EDUFU. 664 p.

Dibog, L., P. Eggleton, L. Norgrove, D.E. Bignell \& S. Hauser, 1999. Impacts of canopy cover on soil termite assemblages in an agrisilvicutural system in Southern Cameroon. Bulletin of Entomological Research, 89: 125-32. doi: 10.1017/ $\underline{\text { So007485399000206 }}$

Diehl, E., L.K. Junqueira \& E. Berti-Filho, 2005. Ant and termite mound coinhabitants in the wetlands of Santo Antonio da Patrulha, Rio Grande do Sul, Brazilian Journal of Biology. 65: 431-437. doi: 10.1590/S1519-69842005000300008.

Diehl E., E. Dihel-Fleig, E.Z. de Albuquerque \& L.K. Junqueira, 2014. Richness of Termites and Ants in the State of Rio Grande do Sul, Southern Brazil. Sociobiology, 61: 145-154. doi: 10.13102/sociobiology.v61i2.145-154.

Donovan, S.E., P. Eggleton \& D.E. Bignell, 2001. Gut content analysis and a new feeding group classification of termites. Ecological Entomology, 26: 356-366. doi: 10.1046/j.13652311.2001.00342.x.

Dray, S., P. Legendre \& P.R. Peres-Neto, 2006. Spatial modelling: a comprehensive framework for principal coordinate analysis of neighbour matrices (PCNM). Ecological Modelling, 19: 483-493. doi: 10.1016/j.ecolmodel.2006.02.015.

Dray, S., R.Pe. Lissier, P. Couteron, M.J. Fortin, P. Legendre, R. Peres-Neto, E. Bellier, R. Bivand, F.G. Blanchet, M.De Ca. Ceres, A.B. Dufour, E. Heegaard, T. Jombart, F. Munoz, J. Oksanen, J. Thioulouse \& H.H. Wagner, 2012. Community ecology in the age of multivariate multiscale spatial analysis. Ecological Monographs, 82: 257-275. doi: 10.1890/11-1183.1.

Eggleton, P., D.E. Bignell, W.A. Sands, B. Waite, T.G. Wood \& J.H. Lawton, 1995. The species richness of termites (Isoptera) under differing levels of forest disturbance in the Mbalmayo Forest Reserve, southern Cameroon. Journal of Tropical Ecology 11: 85-98. doi: 10.1017/So266467400008439.

Eggleton, P., R. Homathevi, D. Jeeva, D.T. Jones, R.G. Davies \& M. Maryati, 1997. The species richness and composition of termites (Isoptera) in primary and regenerating lowland dipterocarp forest in Sabah East Malaysia. Ecotropica, 3: 11928.

Eggleton, P., D.E. Bignell, S. Hauser, L. Dibog, L. Norgrove \& B. Madong, 2002. Termite diversity across an anthropogenic disturbance gradient in the humid forest zone of West Africa. Agriculture Ecosystems and Environment, 90: 189-202. doi: 10.1016/S0167-8809(01)00206-7.

Emerson, A.E., 1952. The neotropical genera Procornitermes and Cornitermes (Isoptera: Termitidae). Bulletin of the American Museum of Natural History, 99: 475-540.

Fernandes, P.M., C. Czepak \& V.R.S. Veloso, 1998. Cupins de montículos em pastagens: prejuízo real ou praga estética?, p.187-210. In: Berti-Filho E. \& L.R. Fontes (Eds.), Cupins: O desafio do conhecimento. Piracicaba: FEALQ. 512 p.

Fontes, L.R., 1985. Acréscimos e correções ao "Catálogo dos Isopteras do Novo Mundo". Revista Brasileira de Entomologia, 17: $137-145$ 
Fontes, L.R.,1992. Keytothegenera of New World Apicotermitinae (Isoptera: Termitidae), p. 242-248. In: Quintero D. \& A. Aiello (Orgs.), Insects of Panama and Mesoamerica. Oxford: University Press. 720 p.

Fontes, L.R., 1995. Sistemática geral de cupins, p. 11-17. In: Berti Filho E. \& L.R. Fontes (Eds.), Alguns aspectos atuais da biologia e controle de cupins. Piracicaba: FEALQ. 184 p.

Garcia J.F., L.P.M. Macedo \& P.S.M. Botelho, 2004. Inimigo ao pé. Cultivar Grandes Culturas, 5: 18-26.

Gathorne-Hardy, F., Syaurani \& P. Eggleton, 2001. The effects of altitude and rainfall on the composition of the termites (Isoptera) of the Leuser Ecosystem (Sumatra, Indonesia). Journal of Tropical Ecology, 17: 379-393. doi: 10.1017/ $\underline{\text { So266467401001262. }}$.

Gontijo, T.A. \& Domingos, D.J. (1991). Guild distribution of some termites from cerrado vegetation in South-east Brazil. Journal of Tropical Ecology, 7: 523-529. doi: 10.1017/ S0266467400005897.

Gotelli, N.J. \& R.K. Colwell, 2001. Quantifying biodiversity: procedures and pitfalls in the measurement and comparison of species richness. Ecology Letters, 4: 379-391. doi: 10.1046/ j.1461-0248.2001.00230.X.

Haifig, I., A.M. Costa-Leonardo \& F.F. Marchetti, 2008. Effects of nutrients on feeding activities of the pest termite Heterotermes tenuis (Isoptera: Rhinotermitidae). Journal of Applied Entomology, 132: 497:501. doi: 10.1111/j.14390418.2008.01288.x.

Hijmans, R.J., S.E. Cameron, J.L. Parra, P.G. Jones \& A. Jarvis, 2005. Very high resolution interpolated climate surfaces for global land areas. International Journal of Climatology, 25: 1965-1978. doi: 10.1002/joc.1276.

Holt, J.A. \& M. Lepage, 2000. Termites and soil properties, p.389407. In: Abe, T., D.E. Bignell \& M. Higashi (Eds.) Termites: Evolution, Sociality, Symbioses, Ecology. Netherlands: Kluwer Academic Publishers. 466p.

Informa Economics FNP South America, 2009. Available on: <http://www.informaecon-fnp.com>. Accessed on: [03.24.2009].

Inoue, T., Y. Takematsu, A. Yamada, Y. Hongoh, T. Johjima, S. Moriya, Y. Sornnuwat, C. Vongkaluang, M. Ohkuma \& T. Kudo, 2006. Diversity and abundance of termites along an altitudinal gradient in Khao Kitchagoot National Park, Thailand. Journal of Tropical Ecology, 22: 609-612. doi: 10.1017/S0266467406003403.

Jones, D.T., 2000. Termite assemblages in two distinct montane forest types at $1000 \mathrm{~m}$ elevation in the Maliau Basin, Sabah. Journal of Tropical Ecology, 16: 271-86.

Jones, D.T. \& M.J.D. Brendell, 1998. The termite (Insecta: Isoptera) fauna of Pasoh Forest Reserve, Malaysia. Raffles Bulletin of Zoology, 46: 79-91.

Jones, D.T. \& P. Eggleton, 2011. Global biogeography of termites: a compilation of sources, p. 477-517. In: Bignell, D.E., Y. Roisin \& N. Lo (Eds.), Biology of termites: a modern synthesis. Dordrecht: Springer, 562 p. doi: 10.1007/978-90-481-3977417.

Junqueira, L.K., E. Diehl \& E. Berti Filho, 2008. Termites in eucalyptus forest plantations and forest remnants: an ecological approach. Bioikos, 22: 3-14.

Krishna, L. \& R.L. Araujo, 1968. A revision of the neotropical termite genus Neocapritermes (Isoptera, Termitidae, Termitinae). Bulletin of the American Museum of Natural History, 138: 83-130.

Laffont, E.R., G.J. Torales, M.O. Arbino, M.C. Godoy, E.A. Porcel \& J.M. Coronel, 1998. Termites associadas a Eucalyptus grandis W.Hill Ex Maiden en el noroeste de la província de Corrientes (Argentina). Revista de Agricultura. 73: 201-214.

Lavelle, P., D. Bignell, M. Lepage, V. Wolters, P. Roger, P. Ineson, O.W. Heal \& S. Dhillion, 1997. Soil function in a changing world: the role of invertebrate ecosystem engineers. European Journal of Soil Biology. 33: 159-193.

Legendre, P. \& L. Legendre, 2012. Numerical Ecology. Elsevier,
$990 \mathrm{p}$.

Magurran, A.E., 2004. Measuring biological diversity. Oxford, Blackwell Science, 256 p.

Mathews, A.G.A., 1977. Studies on termites from the Mato Grosso State, Brazil. Rio de Janeiro: Academia Brasileira de Ciências, $267 \mathrm{p}$

McGill, B.J., R.S. Etienne, J.S. Gray, D. Alonso, D. Marti, M.J. Anderson, H.K. Benecha, M. Dornelas, B.J. Enquist, J.L. Green, F. He, A.H. Hurlbert, A.E. Magurran, P.A. Marquet, B.A. Maurer, A. Ostling, C.U. Soykan, K.I. Ugland \& E.P. White, 2007. Species abundance distributions: moving beyond single prediction theories to integration within an ecological framework. Ecology Letters, 10: 995-1015 doi: 10.1111/j.1461-0248.2007.01094.x.

Menzel, L.V.A. \& E. Diehl, 2008. Reproductive strategies of Cortaritermes fulviceps (Silvestri) (Isoptera, Termitidae, Nasutitermitinae) under laboratory conditions. Sociobiology, 51: 719-731.

Menzel, L.V.A. \& E. Diehl, 2010. Soil Choice for Colony Foundation by Cortaritermes fulviceps (Isoptera, Termitidae, Nasutitermitinae). Sociobiology, 55: 471-487.

Mill, A.E., 1983. Generic keys to the soldier caste of the New World Termitidae (Isoptera: Insecta). Systematic Entomology. 8: 179-190. doi: 10.1111/j.1365-3113.1983.tbo0478.x.

Miranda, C.S., A. Vasconcellos \& A.G. Bandeira, 2004. Termites in sugar cane in Northeast Brazil: ecological aspects and pest status. Neotropical Entomology, 33: 237-241. doi: 10.1590/ S1519-566X2004000200015.

Novaretti, W.R.T. \& L.R. Fontes, 1998. Cupins: Uma grave ameaça à cana-de-açúcar no Nordeste do Brasil, p.163-172. In: Berti Filho E. \& L.R. Fontes (Eds.), Cupins: O desafio do conhecimento. Piracicaba: FEALQ. 512 p.

Oliveira, P.S. \& K. Del-Claro, 2005. Multitrophic interactions in the Brazilian savanna: ant hemipteran systems, associated insect herbivores, and host plant, p. 414-438. In: Burslem, D., M. Pinard \& S. Hartley (Eds.), Biotic interaction in the Tropics: their role in the maintenance of species diversity. London: Cambridge University Press. 580 p. doi: 10.1017/ CBO9780511541971.018.

Oksanen, J.F., G. Blanchet, R. Kindt, P. Legendre, P.R. Minchin, R.B. O'Hara, G.L Simpson, P. Solymos, M.H.M. Stevens \& H. Wagner, 2013. Vegan: Community Ecology Package. $\mathrm{R}$ package version 2.0-9. Available on: <http://CRAN.Rproject.org/package $=$ vegan $>$.

Palin, O.F., P. Eggleton, Y. Malhi, C.A.J. Girardin, A. RozasDávila \& C.L. Parr, 2011. Termite diversity along an AmazonAndes elevation gradient, Peru. Biotropica 43: 100-107. doi: 10.1111/j.1744-7429.2010.00650.x.

R Core Team, 2013. R: A language and environment for statistical computing. R Foundation for Statistical Computing, Vienna, Austria. Available on: <http://www.R-project.org/>.

Rezende, B.R., 2012. Hábitos alimentares de cupins SulAmericanos da família Termitidae (Insecta: Isoptera).. Dissertação (Mestrado - PPG em Biologia Animal) Universidade de Brasília. 46 p.

Rocha, M.M. \& E.M. Cancello 2009. Revision of the Neotropical termite genus Orthognathotermes Holmgren (Isoptera: Termitidae: Termitinae). Zootaxa, 2280: 1-26.

Rocha, M.M., E.M. Cancello \& C. Cuezzo, 2011. A new genus and species of mandibulate nasute termite (Isoptera, Termitidae, Syntermitinae) from Brazil. Zookeys, 148:125-134. doi: 10.3897/zookeys.148.1278.

Rocha, M.M., E.M. Cancello \& T.F. Carrijo, 2012a. Neotropical termites: revision of Armitermes Wasmann (Isoptera, Termitidae, Syntermitinae) and phylogeny of Syntermitinae. Systematic Entomology, 37: 793-827. doi: 10.1111/j.13653113.2012.00645.X.

Rocha, M.M., T.F. Carrijo \& E.M. Cancello, 2012b. An illustrated key to the soldiers of Cyranotermes Araujo with a new species from Amazonia (Isoptera: Termitidae: Nasutitermitinae). Zootaxa. 3196: 50-57. 
Roberts, D.W., 2013. labdsv: Ordination and Multivariate Analysis for Ecology. R package version 1.6-1. Available on: $<$ http://CRAN.R-project.org/package=labdsv $>$.

Siqueira, T., L.M. Bini, F.O. Roque, S.R.M. Couceiro, S. TrivinhoStrixino \& K. Cottenie, 2012. Common and rare species respond to similar niche processes in macroinvertebrate metacommunities. Ecography, 35: 183-192. doi: 10.1111/ j.1600-0587.2011.06875.x.

Singh, M. \& N.B. Singh, 2001. Application of insecticide for termite control and its effect on yield contributing characters in sugarcane. Sugar Tech, 3: 146-153.

Sleaford, F., D.E. Bignell \& P. Eggleton, 1996. A pilot analysis of gut contents in termites from the Mbalmayo Forest Reserve, Cameroon. Ecological Entomology, 21: 279-288. doi: 10.1111/ j.1365-2311.1996.tb01245.x.

Souza, H.B. de A., W de F. Alves \& A. Vasconcellos, 2012. Termite assemblages in five semideciduous Atlantic Forest fragments in the northern coastland limit of the biome. Revista Brasileira de Entomologia, 56: 67-72. doi:10.1590/So08556262012005000013.

Tokeshi, M., 1999. Species Coexistence: ecological and evolutionary perspective. London: Blackwell Science Ltd., $454 \mathrm{p}$.
Valério, J.R., 2006. Cupins-de-montículo em pastagens. Campo Grande, MS: Embrapa Gado de Corte, 33 p.

Wardell, D.A., 1987. Control of termites in nurseries and young plantations in Africa: established practices and alternative courses of action. Common Wealth Forest Review, 66: 7789.

Wilson, J.B., 1991. Methods for fitting dominance/diversity curves. Journal of Vegetation Science, 2: 35-46. doi: $10.2307 / 3235896$.

\section{Received in: $01 / 20 / 2015$}

Accepted in: 05/13/2015

\section{Suggested citation:}

Junqueira, L.K., E.R. Gonçalves \& L.M.C. Teixeira, 2015. Termite Communities in Sugarcane Plantations in Southeastern Brazil: an Ecological Approach EntomoBrasilis, 8 (2): 105-116.

Available in: $\underline{\text { doi:10.12741/ebrasilis.v8i2.502 }}$
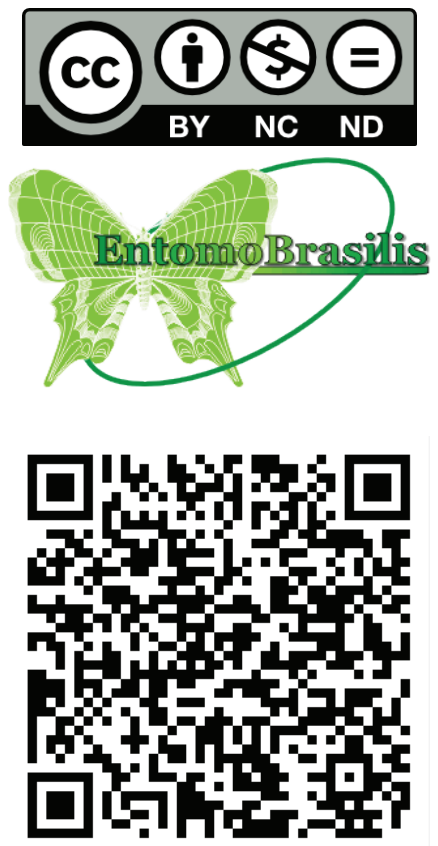